\title{
Role pracovně rehabilitačního střediska v procesu pracovní integrace osob se zdravotním postižením
}

\section{The Role of the Vocational Rehabilitation Center in the Process of Work Integration of People with Disabilities}

Petr Džambasovi ${ }^{1}$, Ašcociace pracovní rehabilitace ČR, z. s., Chomutov; Jihočeská univerzita České Budějovice

\section{Abstrakt}

Pracouní rehabilitace je systémový nástroj Ưřadu práce ČR, zaměřený na získání a udržení zaměstnání osob se zdravotním postižením. V rámci projektu ESF aktuálně probíhá vývoj a testování nového konceptu „pracovně rehabilitačního střediska“, které se v budoucnu může stát partnerem ÚP ČR při zabezpečování pracovní rehabilitace a přispět ke zvýšení včasnosti a dostupnosti pracovní rehabilitace. Článek popisuje výchozí stav pracovní rehabilitace v ČR a aktuální výzvy, kterým tato oblast aktuálně čelí.

\section{Klíčová slova}

rehabilitace, pracovní rehabilitace, pracovně rehabilitační centra, osoby se zdravotním postižením

\section{Abstract}

Vocational rehabilitation is a systemic tool of the Labor Office of the Czech Republic, intended for obtaining and maintaining employment of persons with disabilities. As part of the ESF project, a new concept of a „vocational rehabilitation center" is currently being developed and tested, which in the future may become a partner of the Labor Office in providing vocational rehabilitation and contribute to increasing the timeliness and availability of vocational rehabilitation. The article describes the initial state of vocational rehabilitation in the Czech Republic and the current challenges that this area is currently facing.

\section{Keywords}

rehabilitation, vocational rehabilitation, vocational rehabilitation center, people with disabilities

Za vrcholný úspěch rehabilitačního procesu je považováno zapojení (či návrat) osoby se zdravotním postižením (OZP) do pracovního procesu. Pro systémovou podporu zaměstnanosti OZP je v ČR od roku 2004 k dispozici pracovní rehabilitace, která je zabezpečovaná Úřadem práce ČR a ročně ji využije v průměru cca 400-500 osob. Klíčovou podmínkou pro úspěch pracovní rehabilitace je její včasné zahájení, bezproblémová dostupnost, promyšlená a efektivní návaznost všech poskytnutých podpor a motivace zapojené osoby k aktivní participaci na rehabilitačním procesu.

Přes řadu pozitivních změn se tento nástroj stále potýká se systémovými nedostatky, zejména v oblasti včasného zapojení všech oprávněných skupin osob. V rámci aktuálně realizovaného projektu ESF dochází k vytváření a pilotnímu ověřování konceptu pracovně rehabilitačních středisek, která mají legislativní oporu v zákoně o zaměstnanosti, ale dosud v ČR nebyla zřízena. Cílem projektu je ověřit, jak přispívají pracovně rehabilitační střediska včasnosti a dostupnosti pracovní rehabilitace v ČR.

\section{Aktuální stav zaměstnanosti OZP v ČR}

V České republice je dlouhodobě více než 400 tis. osob² se zdravotním postižením v ekonomicky aktivním

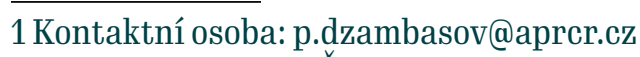

2 K 31.12.2020 bylo v ČR dle důchodové statistiky České správy sociální zabezpečení 417639 invalidních důchodců. Dostupné z https://www.cssz.cz/duchodova-statistika. Dle kvalifikovaného odhadu je v ČR dále cca 20 tis. osob zdravotně znevýhod- 
věku. Dle dostupných statistických dat ${ }^{3}$ je zaměstnáno přibližně 30 \% z nich, přitom polovina je zaměstnaná na chráněném trhu práce. Přibližně 2/3 zdravotně postižených osob se nachází mimo trh práce (tzn. nepracují, nepodnikají, nestudují, nejsou na rodičovské dovolené). Ke konci června 2021 bylo v evidenci ÚP ČR téměř 40 tis. ${ }^{4}$ uchazečů o zaměstnání se zdravotním postižením. V evidenci uchazečů o zaměstnání je tak v tuto chvíli cca 9 \% všech OZP v ekonomicky aktivním věku.

Je však potřeba upřesnit, že statistika nezaměstnanosti zahrnuje pouze ty osoby, které jsou evidovány jako uchazeči či zájemci o zaměstnání na ÚP ČR. Určitá část ekonomicky neaktivních osob se zdravotním postižením se nachází mimo jakoukoliv evidenci. Týká se to např́klad osob ve 3. stupni invalidity (aktuálně cca 168 tis. osob), které však až na výjimky nemohou vstupovat do evidence uchazečỏ o zaměstnání, a tudíž se ve statistice nezaměstnaných neobjevují. Přesto část těchto osob, při vhodném výběru zaměstnání, případně s další podporou či úpravou pracovních podmínek, je schopna konkurenceschopného pracovního výkonu, a to i na otevřeném trhu práce. Dle kvalifikovaného odhadu se může jednat o 5-10 \% ekonomicky neaktivních 0ZP, kteří se nacházejí mimo evidenci uchazečů či zájemců o zaměstnání (cca 10-20 tis. osob).

„Zdravotní postižení pro účely pracovní integrace je ve většině případů hodnoceno z hlediska jeho dopadu na pracovní život. Je pojímáno především jako omezení nebo ztížení možnosti vykonávat pracovní činnost a účastnit se pracovního života v důsledku zdravotního stavu.“ (Kotíková, 2014, 7)

Jak uvádí Dutta, u části osob se zdravotním postižením, kteří jsou motivovaní k účasti na pracovním procesu, ale pracovní začlenění se jim dlouhodobě nedaří realizovat, „vede tento stav ke snížení kvality života, resp. mají skon k vyšší prevalenci deprese a úzkostné poruchy, častěji uživají alkohol a uvádějí nižší skóre sebeúcty a sebevědomí." (2008, 326)

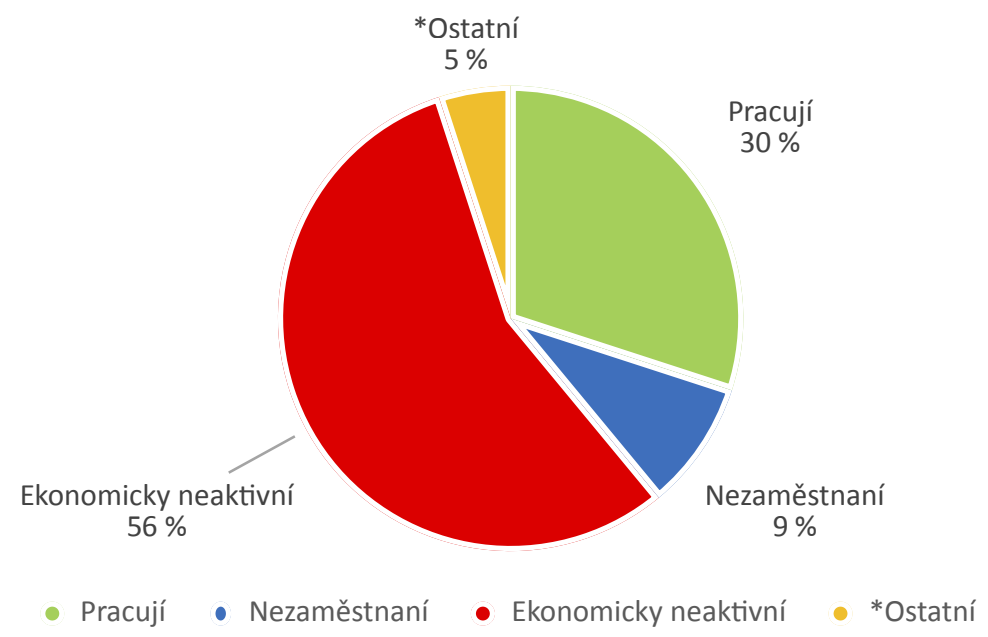

Graf č. 1- Struktura 0ZP podle ekonomické aktivity

(Zdroj: vlastní zpracování z dostupných statistických dat ČSSZ, ČSÚ a ÚP ČR)

*ostatní = studenti, rodiče na rodičouské dovolené

Zákon o zaměstnanosti za tímto účelem garantuje osobám se zdravotním postižením právo na využití tzv. „pracovní rehabilitace“, která je od svého počátku koncipována jako jeden z nástrojů aktivní politiky za-

něných.

3 Výběrové šetření OZP, ČSÚ 2018 dostupné z: https://www.czso.cz/csu/czso/vyberove-setreni-osob-se-zdravotnim-postizenim-2018

4 K 30.6.2021 bylo v evidenci uchazečů o zaměstnání ÚP ČR 39.318 osob se zdravotním postižením. Statistika nezaměstnanosti ÚP ČR. Dostupné z https://data.mpsv.cz/web/data/mesicni-nezamestnanost-vyvoj-na-trhu-prace-ve-vybranem-roce 
městnanosti Úřadu práce ČR. Přestože je tento nástroj v gesci úřadu práce, není pracovní rehabilitace určena pouze pro evidované uchazeče o zaměstnání. Zákon o zaměstnanosti garantuje právo na bezplatné využití pracovní rehabilitace jakékoliv osobě se zdravotním postižením, která o ní požádá.

Mezi oprávněnými osobami jsou dle zákona jak osoby, které jsou již uznané ČSSZ jako invalidní, tak také osoby v dočasné pracovní neschopnosti (tzn. ještě před přiznáním invalidity), za předpokladu, že se jejich zdravotní stav jeví jako dlouhodobě nepříznivý a se zapojením do pracovní rehabilitace vyjádří písemný souhlas jejich ošetřující lékař. 0 pracovní rehabilitaci si dokonce může požádat i osoba dosud zaměstnaná, pokud je její další udržení na trhu práce ze zdravotních důvodů ohroženo.

Aktuální výzvou je nastavení systému, který by dokázal poskytnout včasnou podporu všem osobám, které jsou vlivem vrozeného či získaného onemocnění ohroženi na trhu práce. Aktuálně probíhající projekt ESF usiluje o rozšíření stávajících možností ÚP ČR při včasném zabezpečení pracovní rehabilitace. Osoby se zdravotním postižením mají zvýšené nároky na vytvoření vhodných podmínek ze strany zaměstnavatelů (úprava pracoviště, zkrácená pracovní doba, flexibilní forma práce atd). Proto je klíčová také úzká součinnost se zaměstnavateli a jejich kvalifikovaná podpora. Většinu těchto specifických požadavků je možné podpořit prostřednictvím vhodně zvolených pracovně - rehabilitačních služeb, za předpokladu, že jsou pro OZP dostupné a včasně zahájené. Projekt pracuje s hypotézou, že spolupráce pracovníkư ÚP ČR s odborným externím týmem pracovně rehabilitačního střediska bude mít pozitivní vliv na vyšší dostupnost a včasnost pracovní rehabilitace.

\section{Koncept pracovně rehabilitačních středisek}

V rámci aktuálně probíhajícího projektu Evropského sociálního fondu s názvem: „Vývoj a pilotní ověření konceptu Pracovně rehabilitačního střediska“ aktuálně vzniká ve spolupráci s MPSV a ÚP ČR koncept odborných středisek, která již od roku 2004 předvídá zákon o zaměstnanosti jako subjekt podílející se ve spolupráci s úřady práce na zabezpečení pracovní rehabilitace (§69, odst. 1 zákona o zaměstnanosti č. 435/2004 Sb.). Tato střediska dosud nebyla v ČR zř́́zena a projekt tak zkoumá možnosti a př́nos tohoto řešení v oblasti podpory zaměstnávání OZP. Nosnou myšlenkou uvedeného konceptu je vybudování externího multiprofesního zařízení, které by bylo schopné účinně vyhledávat motivované ekonomicky neaktivní OZP (případně osoby po vážné nemoci či úrazu ohrožené ztrátou zaměstnání), podpořit jejich včasný přestup do pracovní rehabilitace a následně být užitečným partnerem ÚP ČR, zapojených účastníkům a zaměstnavatelům při zabezpečení individuálně naplánovaného komplexu pracovně - rehabilitačních služeb.

Vytvářený koncept předpokládá zapojení tří stěžejních profesí: ergoterapeuta, osobního poradce a pracovního konzultanta se zkušeností v oblastí pracovní integrace OZP. Projektový záměr předpokládá vznik těchto středisek v rámci již existujících organizací, které se dlouhodobě věnují sociální a pracovní integraci OZP. Cílem tak není budování ekonomicky nákladné sítě nových subjektů, ale naopak využití synergie již existujících organizací, které mají kvalifikační předpoklady a potenciál pro rozššření své činnosti o tuto veřejnou službu.

Uvedený koncept je od letošního roku pilotně testován v rámci 3 vybraných organizací (Asociace pracovní rehabilitace CR, Česká abilympijská asociace, Agapo). V okresech Chomutov, Pardubice a Brno bude v průběhu let 2021-2022 zapojeno do pilotního ověření celkem 120 osob se zdravotním postižením. Cílem je zapojit především osoby časně po získání invalidity (nap̌̌s. studenty a žáky se speciálními vzdělávacími potřebami) a osoby po vážné nemoci či úrazu v dočasné pracovní neschopnosti. Projekt je v uvedených okresech realizován ve spolupráci s kontaktními pracovišti ÚP ČR. Součástí projektu je také rozsáhlý výzkum dopadů tohoto řešení do oblasti včasnosti a dostupnosti pracovní rehabilitace a cost - benefit analýza ekonomické udržitelnosti navrženého řešení, resp. dopad navrženého řešení do oblasti veřejných financí.

Po zapojení do projektu a podání žádosti o pracovní rehabilitaci jsou v uvedených okresech pro účastníky k dispozici všechny formy pracovní rehabilitace, mezi které patří např. individuální či skupinové poradenství, ergodiagnostika, bilanční a pracovní diagnostika, rekvalifikace, asistence v zaměstnání, příprava k práci a další. Klíčovou součástí pracovně rehabilitačních služeb je vždy zprostředkování zaměstnání, které zahrnuje nejen výběr vhodného zaměstnání, ale také podporu zaměstnavatelů při vytváření pracovních míst pro 0ZP, zhodnocení pracovních podmínek na konkrétním pracovišti či poradenství zaměstnavatelům při přizpůsobení pracovního místa potřebám konkrétního uchazeče. Veškeré aktivity 
projektu jsou hrazeny z prostředků ESF a státního rozpočtu ČR.

\section{Výz kum}

V rámci projektu bude proveden rozsáhlý výzkum, jehož cílem je ověřit dopad inovačního řešení (zřízení pracovně rehabilitačních středisek) do systému pracovní rehabilitace - tzn. měření efektivity a hospodárnosti inovativního řešení v porovnání s aktuální podobou systému pracovní rehabilitace, resp. systémem pracovní integrace OZP v CR.

Cílem výzkumu je:

1.) Ověřit dopad na šíři zapojení cílové skupiny (dostupnost) a včasnost zapojení.

2.) Ověřit dopad projektu na získání a udržení zaměstnání u cílové skupiny v porovnání s kontrolní skupinou.

3.) Evaluace efektivity nového řešení (evaluace výdajů a př́ijmů v oblasti veřejných financí spojených s novým řešením) v porovnání se stávajícím řešením.

Do pilotního ověření bude zařazeno 120 0ZP, a to rovnoměrně rozložených do 3 okresů místa pilotního ověření (40 Chomutov, 40 Brno, 40 Pardubice). U cílové skupiny očekáváme, že v důsledku účasti v projektu dojde u části z nich k jejich pracovnímu uplatnění. Z pohledu hlavního cíle projektu dojde k ověření funkčnosti navrženého řešení a jeho evaluaci v rámci zvýšení včasnosti a dostupnost pracovní rehabilitace.

Kontrolní skupiny byly sestaveny tak, aby se kromě obdržené podpory v maximální možné míře podobaly cílové skupině. Za klíčové faktory, které mají vliv na dopad poskytnuté intervence, byly identifikovány tyto proměnné:

- Věk

- Pohlaví

- Stupeň dosaženého vzdělání

- Stupeň postižení

- Místo bydliště (kraj, okres)

Kontrolní skupina A je složena ze 120 0ZP srovnatelného věku, pohlaví, vzdělání a stupně postižení mimo evidenci ÚP ČR - ve 3 okresech realizace projektu - 3 x 40 osob, které nevyužívají žádné podpory v oblasti pracovní integrace - data vybraných respondentů budou poskytnuta na základě informovaného souhlasu.

Kontrolní skupina B je složena ze 120 0ZP srovnatelného věku, pohlaví, vzdělání a stupně postižení zapojených do pracovní rehabilitace bez intervence pracovně rehabilitačního střediska.

Hlavní evaluační otázky:

1.) Do jaké míry pracovně rehabilitační středisko přispěje k včasnému zapojení dalších ohrožených skupin OZP, které dosud do pracovní rehabilitace zapojeny nejsou (nebo pouze ve výjimečných případech)?

2.) Jak pracovně rehabilitační středisko přispěje k získání a udržení zaměstnání u účastníků pracovní rehabilitace?

3.) Jaká je nákladová efektivita pracovně rehabilitačního střediska a jaké jsou předpoklady udržitelnosti navrženého řešení?

\section{Metodologie výzkumu}

Pro hodnocení efektů pracovně rehabilitačního střediska na zapojeného účastníka bude použita kontrafaktuální dopadová evaluace (CIE) založená na metodě PSM doplněná metodou DiD (difference in difference). Intervenční skupinu a obě kontrolní skupiny (A, B) budeme primárně porovnávat v režimu 40x40 x 40, a to z důvodu srovnatelnosti proměnných (malého rozptylu dat) ve všech vzájemně porovnávaných skupinách. Důvodem je snaha o zamezení vlivu odlišnosti prostředí v jednotlivých krajích (které se často podstatně liší například u okresních úřadů práce, které podléhají centrálnímu krajskému vedení ÚP, které nastavuje často velmi rozdílné podmínky pro realizaci PR - obdobná situace je také u OSSZ).

Rozdíly mezi kraji (respektive potenciální vliv konkrétního místa bydliště intervenční a kontrolní skupiny) bude jedním z předmětů výzkumu. Zároveň chceme zamezit tomu, aby lokální rozdíly podmínek zkreslily celkový výsledek. Výzkum bude tedy primárně řešen z pohledu 3 samostatně zkoumaných lokalit. Z výše uvedených důvodů budeme primárně porovnávat intervenční a obě kontrolní skupiny v rámci jednoho kraje - u kontrolní skupiny A dokonce v rámci stejného okresu.

V druhé fázi však budeme porovnávat výsledky mezi sebou. Tzn. vzájemné porovnání 3 souborů dat. 
Pokud bude skupina dostatečně homogenní, počítáme i s tím, že budeme porovnávat celé vzorky dat mezi sebou. Považujeme za důležité zhodnotit dopad inovace jak v porovnání se stávajícím stavem, tak i se situací, kdy osoby nejsou zasaženi žádnou intervencí, abychom odhalili jednak rozdíl v obou přístupech při zabezpečování PR (tzn. IS x KSB), tak i rozdíl se situací, kdy žádná intervence neprobíhá (IS x KSA). K prokázání rozdílu mezi oběma přístupy při zabezpečování PR bude sloužit mimo jiné také výsledek porovnání mezi KSA a KSB.

\section{Závěr}

Vytvářený koncept pracovně rehabilitační středisek usiluje o přímý dopad do oblasti pracovní rehabilitace, která se po jejich zavedení do praxe stane dostupnějším a včasněji aplikovaným nástrojem podpory pro širší spektrum oprávněných motivovaných osob se zdravotním postižením, kterým prospěje při jejich návratu či udržení se na pracovním trhu a bude mít prokazatelný dopad na zvýšení kvality jejich života. Více informací o projektu na www.pracovnirehabilitace.cz.

\section{Literatura}

Dutta A. et. Al. (2008). Vocational Rehabilitation Services and Employment Outcomes for People with Disabilities: A United States Study. In: Journal of Occupational Rehabilitation,, str. 326 Dostupné z: https://link. springer.com/content/pdf/10.1007/s10926-008-9154-z.pdf

Kotíková, J., Schebelle, D. \& Vychová, H. (2014). Zaměstnávání osob se zdravotním postižením v České republice - výsledky analýzy práoní úpravy a praxe na trhu práce. In FÓRUM sociální politiky 5/2014. Praha, VUPSV.

Měsíční statistika struktury uchazečủ a volných pracovních míst 6_2021. [online]. Praha: Úřad práce České republiky. [cit. 2021-7-15].

Dostupné z: https://data.mpsv.cz/web/data/mesicni-nezamestnanost-vyvoj-na-trhu-prace-ve-vybranem-roce

Roční statistika důchodového pojištění 2020. [online]. Praha: Česká správa sociálního zajištění. [cit. 20217-15].

Dostupné z: https://www.cssz.cz/duchodova-statistika

Výběrové šetření osob se zdravotním postiženým 2018. [online]. Praha: Český statistický úřad. [cit. 2021-615]. Dostupné z: https://www.czso.cz/csu/czso/vyberove-setreni-osob-se-zdravotnim-postizenim-2018

Zákon č. 435/2004 Sb. o zaměstnanosti ve znění pozdějších předpisů, 2004. Sbírka zákonů České republiky. ISSN 1211-1244

Zákon č. 108/2006 Sb. o sociálních službách ve znění pozdějších předpisů, 2006. Sbírka zákonů České republiky. ISSN 1211-1244

Zpráva o činnosti Úřadu práce ČR (2015-2019). [online]. Praha: Úřad práce České republiky. [cit. 2021-6-15]. Dostupné z: https://www.uradprace.cz/zprava-o-cinnosti

\section{Informace o autorech}

\section{Mgr. Petr Džambasov}

Ředitel Centra ucelené rehabilitace a místopředseda Asociace pracovní rehabilitace ČR. Sociální pracovník, projektový manažer, supervizor, lektor vzdělávání dospělých. Absolvent FSE UJEP a FHS UK Praha. Doktorand Jihočeské Univerzity v Českých Budějovicích.

Telefon: +420 776534207

Email: p.dzambasov@aprcr.cz

URL: www.aprcr.cz 